\title{
技術解説
}

\section{文字多重 放送の伝送特性}

正会員山田宰

テレビ多重文字放送の伝送特性に関して, ディジタル信号を伝送するときの放送特有の問題点 と, 誤り訂正符号の訂正効果を中心に, 我が国の文字放送の伝送パラメータ，サービス品質などに ついて述べる。

\section{1. まえ がき}

テレビ信号の垂直㛿線期間に，文字・図形情報を多 重伝送して, 家庭のテレビ受像機に表示する文字多重 放送は, 1985 年 11 月から放送開始して以来, 現在で は，NHK，各民間放送機関とも，サービスを全国規 模に拡大しつつあり，受信機の普及も徐々にではある が着実に増加している。

文字放送は研究を開始した 10 数年前から, 文字・ 図形等の提示機能, 符号系, 伝送特性等, 種々の検討 が重ねられ，1985 年 3 月の電波技術審議会の答申を もとに標準方式が定められ実用化に至った ${ }^{12)}$.

特に伝送特性の問題については, ゴースト妨害，イ ンパルス妨害等の多い地上系テレビアナログ伝送路に ディジタル信号を通すことのむずかしさから，ビット
レート, 波形整形, 誤り訂正・検出などに関し,さま ざまな検討がなされてきた ${ }^{3)}$. 以下では，放送伝送路 特有の問題点, 我が国の文字放送の伝送特性の概要お よび文字放送サービスの伝送品質などについて解説す る。

\section{2. 文字放送信号の流れ}

文字放送信号の一般的な流れを図 1 に示す．情報で ある各文字・図形は，伝送路の誤り訂正・検出符号化 とは独立に効率良く符号化され，送出順に従って一定 ブロック長に区切られパケット化される。この一定ブ ロック長の情報に対して, 誤り訂正のためのパリティ ビットが，情報ビットをもとにして計算した演算結果 として付加される.また, 必要に応じて誤り検出（能 力）を強化するために，この情報部に CRC（Cyclic

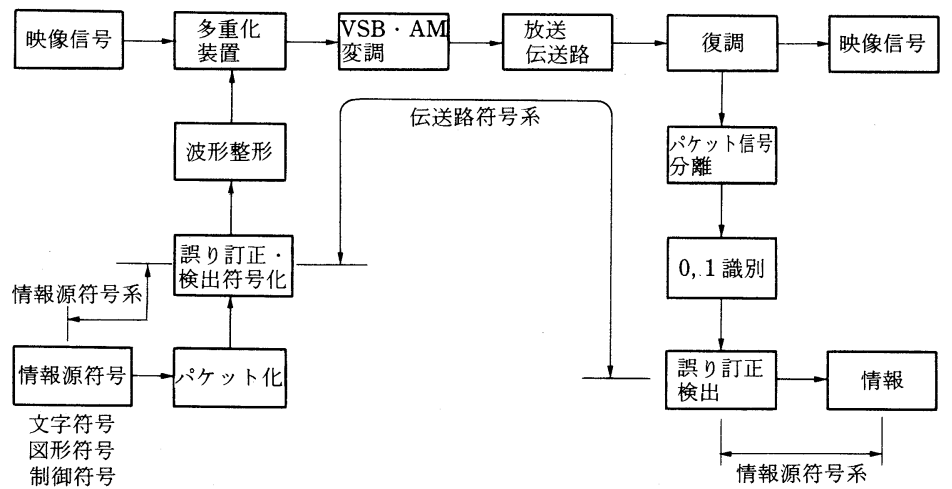

図 1 文字信号の流れ

† NHK 放送技術研究所

"Transmission Quality of Teletext" by Osamu Yamada (NHK

Science and Technical Research Laboratories, Tokyo) 
Redundancy Check）が付加される.

信号は, 矩形 NRZ（Non Return Zero）パルス波形 として出力されるが, 各ビット間の符号間干涉を極力 抑圧するため波形整形フィルタを通してテレビ垂直帰 線期間に多重する.

テレビ放送信号は伝送路に扔いて，ビル反射による ゴースト妨害, 自動車や工場からのインパルス妨害, あるいは，放送波中継での波形ひずみなどの妨害を受 ける．これらの妨害は, 従来のテレビ信号に対しては それほどの影響がない場合でも，ディジタル信号であ る文字信号に対しては, 直接, 信号の劣化につなが り, ビット誤り率を悪化させる原因になっている．

受信機で復調された信号は, 垂直帰線期間の文字信 号だけが分離され，“0”，“1”に識別された後, 信 号の区切りの識別信号, 表示タイミング信号等の再生 と符号の誤り訂正・検出がなされる，誤りがない場合 には, 受信機はその符号を解釈し, 文字・図形として ブラウン管へ表示する。

\section{3. 伝送パラメータ}

\section{1 ディジタル信号の伝送}

ディジタル信号の波形 $g(t)$ とその周波数スペクト ル $G(f)$ は, 次式で示すフーリエ変換とフーリエ逆変 換によって関係づけられる。 $g(t)$ は伝送路特性が $G(f)$ の伝送路に単位インパルスを与えたときの出力 波形に相当する.

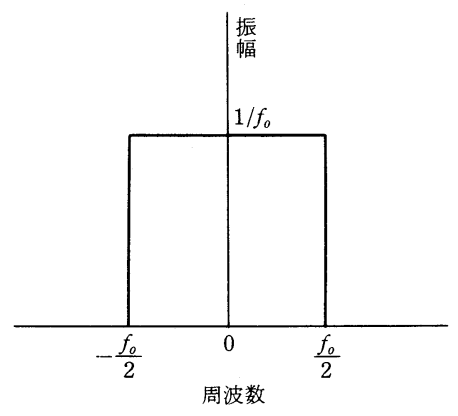

(a) 理想低域フィルタ

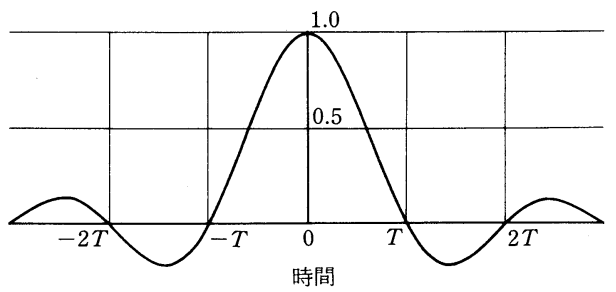

(b) 理想低域フィルタのインパルス応答

図 2 理想低域フィルタとそのインパルス応答

$$
\begin{aligned}
& G(f)=\int_{-\infty}^{\infty} g(t) e^{-j 2 \pi f t} d t \\
& g(t)=\int_{-\infty}^{\infty} G(f) e^{j 2 \pi f t} d f
\end{aligned}
$$

単位インパルスを振幅 $1 / f_{0}$, 帯域幅士 $f_{0} / 2$ の理想低 域フィルタを通過させたときの応答波形 $g_{1}(t)$ は,

$$
g_{1}(t)=\frac{\sin \pi F t}{\pi F t} \quad\left(F=\frac{1}{T}\right)
$$

となる (図 2). ただし, $\sin 0 / 0=1$ とする. $g_{1}(t)$ は標 本化関数（あるいは sinc 関数）と呼ぶ.（3)式は $g_{1}(n T)=0$ (ただし $, T=1 / f_{0}, n=1,2,3, \cdots$ ) であり， ナイキストの第 1 基準を満足しており, 各パルス間の 符号間干渉は生じない.

しかし, 実際の伝送では理想フィル夕の実現は困難 であるし，時間領域での信号が $1 / t$ のオーダで無限に 広がるため, カットオフ周波数（伝送特性）の少しの ずれが大きな符号間干渉をひきおこすことになり，現 実的ではない。このため, 理想フィルタのカットオフ 周波数を中心にコサイン 2 乗特性（奇関数ならよい） を重畳したフィルタを通し，なるべく信号波形が広が ないような特性とし; それほど正確な伝送特性の確保 が必要ないようにしている.コサイン 2 乗特性は次式 のようになる。

$$
G(f)=\left\{\begin{array}{rl}
1 & 0 \leqq f<\frac{f_{0}-f_{x}}{2} \\
\cos ^{2}\left(f-\left(\frac{f_{0}-f_{x}}{2}\right)\right) \frac{f_{0}-f_{x}}{2} & \leqq f<\frac{f_{0}+f_{x}}{2} \\
0 & \frac{f_{0}+f_{x}}{2} \leqq f
\end{array}\right.
$$

$\alpha=f_{x} / f_{0}$ をロールオフ率と呼んでいる.
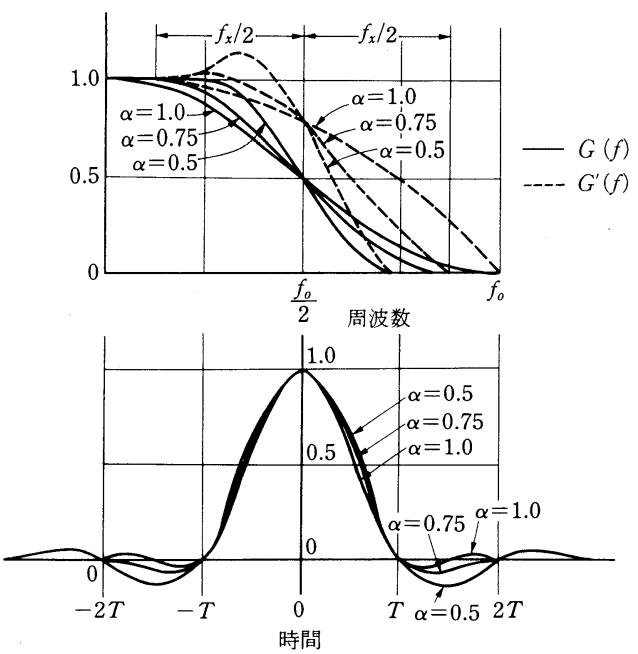

図 3 各ロールオフ率の周波数特性とインパルス応答 


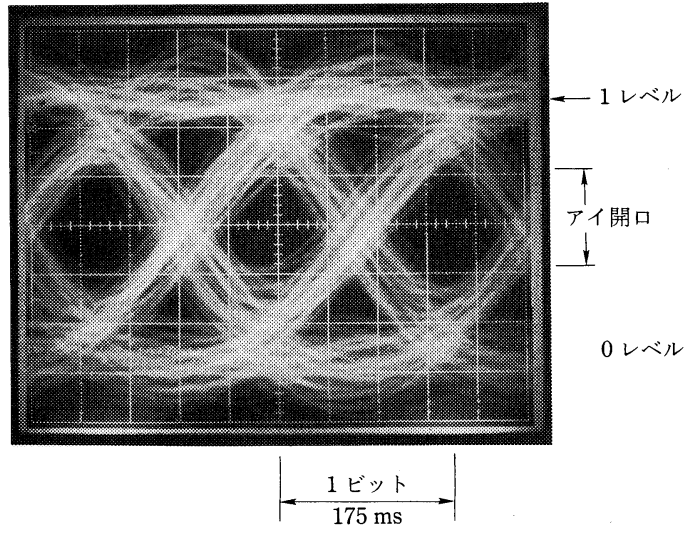

写真 1 群遅延により劣化した文字信号

実際の送出装置では, インパルス波形ではなく矩形 波形を伝送することになるので, $(4)$ 式の $G(f)$ の特 性を得るためには，(4) 式を矩形波形の周波数スペク トルで割算した特性のフィルタ $G^{\prime}(f)$ を通せばよい.

$$
G^{\prime}(f)=G(f) \frac{\pi f T}{\sin (\pi f T)}
$$

ロールオフ率 $\alpha=0.5,0.75,1.0$ 各々のフィル夕特性 とインパルス応答を図 3 に示す.

\section{2 ビット誤り率}

伝送路が（１）で述べた理想特性であれば，受信側で の“ $0 ”, “ 1 ” の$ 識別点での符号間干渉はなく, ただ 単なる熱雑音の妨害によるビット誤りのみを考慮すれ ばよい。しかし, 実際の伝送路では, ゴースト妨害, 放送波中継段の群遅延特性の変化等により符号間干渉 を生じ信号の識別余裕度が劣化する. 写真 1 は, 文字 信号をクロック信号に同期させて見た時の信号劣化を 生じた例であり，識別部分が目の形をしていることか らアイパターンと呼んでいる。“0”, “1”信号を送 出した時の定常值のレベルと, 中心開口部の高さの比 をアイ開口率と呼び, 一般にディジタル伝送特性の品 質を示す目やすとしている. 当然, アイの幅も受信機 のクロック信号のジッタの余裕度を示すもので, 受信 品質に関係してくる.

標準偏差 $\sigma_{n}$ のガウス雑音における瞬時振幅值 $n$ の 確率密度は $\left(1 / \sigma_{n} \sqrt{2 \pi}\right) e^{-n^{2} / 2 \sigma \pi} d n$ なので, 振幅值 $A$ 以 上を誤りとすると, 誤り率 $P(\varepsilon \mid 0)$ は,

$$
\begin{aligned}
P(\varepsilon \mid 0) & =\frac{1}{\sigma_{n} \sqrt{2 \pi}} \int_{A}^{\infty} e^{-n^{2} / 2 \sigma z} d n \\
& =\frac{1}{\sigma_{n} \sqrt{2 \pi}} \int_{A / \sigma_{n}}^{\infty} e^{-x^{2} / 2} d x \\
& =Q\left(\frac{A}{\sigma_{n}}\right)
\end{aligned}
$$

で表すことができる．信号“1”がレベル 1 であれば

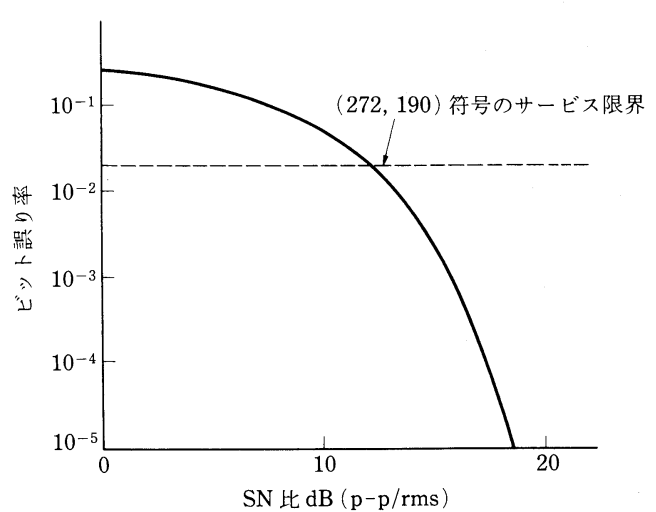

図 4 ガウス雑音によるビット誤り率

$A=1 / 2$ となる.アイ開口率が劣化した場合のビット 誤り率の上限は $(6)$ 式において, $A^{\prime}=\eta A$ として計算 すればよい。なお，(6)式はこのままの形では計算で きないが, 数值計算で求めた数值表が用意されてい る.また， $Q$ に関する良い近似式は(7)式で与えら れる5

$$
Q(x) \simeq \frac{1}{x \sqrt{2 \pi}}\left(1-\frac{0.7}{x^{2}}\right) e^{-x^{2} / 2} \quad x>2
$$

$\mathrm{SN}$ 比とビット誤り率の関係を図 4 に示す.

\section{3 信号規格}

我が国の文字放送では，テレビの伝送帯域幅が 4.2 $\mathrm{MHz}$ に制限されていること, なるべく高いビットレ 一トが必要なこと, 充分なアイ開口率とビット誤り率 が確保できること, 受信機側での安定な信号が簡単に できるようにビットレートを色副搬送波周波数とは $m / n$ 倍の関係にあること等, 詳細にわたる検討と室 内・野外伝送実験の結果, ビットレート $f_{c}$ とロール オフ率 $\alpha$ は,

$$
\begin{aligned}
f_{c} & =\frac{8}{5} f_{s c} \quad\left(f_{s c}: \text { 色副搬送波周波数 }\right) \\
& =5.73 \mathrm{MHz} \\
\alpha & =0.6
\end{aligned}
$$

と定められた ${ }^{3)}$.

また，多重信号のレベルについては，オーバシュー トが妨害にならないように決めなければならない， $\alpha$ $=0.6$ の時のオーバシュート量は $18.3 \%$ になることが わかっている.さらに，受信機が包絡線検波の場合に は，多重レベルが $80 \%$ 以上ではアイ開口率に差がな いので, オーバシュートの点からは, 多重レベルは $80 \%$ 程度となるが, 安全を見込んで $70 \%$ と定めてい $3^{3)}$.

我が国および諸外国の文字放送信号パラメータの一 
表 1 各国のテレテキストの諸元

\begin{tabular}{|c|c|c|c|c|c|c|c|c|c|c|}
\hline & $\begin{array}{l}\text { テレビ } \\
\text { 方 式 }\end{array}$ & $\begin{array}{l}\text { テレビ } \\
\text { 帯 域 } \\
(\mathrm{MHz})\end{array}$ & $\begin{array}{l}\text { ビット } \\
\text { レート } \\
(\mathrm{Mb} / \mathrm{s})\end{array}$ & $\begin{array}{l}\text { 波形 } \\
\text { 整形 }\end{array}$ & 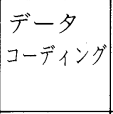 & $\begin{array}{c}1 \text { の } \\
\text { レベル } \\
(\%)\end{array}$ & $\begin{array}{c}\text { データ } \\
\text { ライン長 } \\
(\text { ビット })\end{array}$ & $\begin{array}{c}\text { ビット } \\
\text { 同 } \quad \text { 期 } \\
\text { (ビット) }\end{array}$ & $\begin{array}{l}\text { フレーミン } \\
\text { グコード } \\
(\text { ビット })\end{array}$ & 誤り保護 \\
\hline $\begin{array}{l}\text { イギリス方式 } \\
\text { (UKteletext) }\end{array}$ & $\mathrm{I} / \mathrm{PAL}$ & 5.5 & 6.94 & $100 \%$ & $\begin{array}{l}2 \text { 値 } \\
\text { NRZ }\end{array}$ & 66 & 360 & 16 & 8 & $\begin{array}{l}\text { 制御：(8,4)ハミング } \\
\text { 文字：パリティー }\end{array}$ \\
\hline $\begin{array}{c}\text { ·ランス方式 } \\
\text { (Antiope) }\end{array}$ & L/SECAM & 6.0 & 6.20 & $\begin{array}{l}\sin ^{2} \\
\text { 波形 }\end{array}$ & $\begin{array}{l}2 \text { 值 } \\
\text { NRZ }\end{array}$ & $\begin{array}{c}\mathrm{A} / \mathrm{S}= \\
7 / 3\end{array}$ & 320 & 16 & 8 & $\begin{array}{l}\text { 制御：( } 8,4) \text { ハミング } \\
\text { 文字：パリティー }\end{array}$ \\
\hline $\begin{array}{l}\text { 北米方式 } \\
\text { (NABTS) }\end{array}$ & M/NTSC & 4.2 & 5.73 & 100 & $\begin{array}{l}2 \text { 值 } \\
\text { NRZ }\end{array}$ & 100 & 288 & 16 & 8 & $\begin{array}{c}\text { 制御：( }(8,4) \text { ハミング } \\
\text { 文字：パリティーor } \\
\text { HVパリティー }\end{array}$ \\
\hline $\begin{array}{l}\text { 日本方式 } \\
\text { (文字放送) }\end{array}$ & M/NTSC & 4.2 & 5.73 & 60 & $\begin{array}{l}2 \text { 值 } \\
\text { NRZ }\end{array}$ & 70 & 296 & 16 & 8 & $(272,190)$ 符号 \\
\hline
\end{tabular}

覧を表 1 に示す.

\section{4. 伝送信号劣化の要因}

文字放送信号を劣化させる主な要因としては，以下 のものが挙げられる.

(1) 弱電界によるもの

(2) 群遅延特性劣化によるもの

(3) ゴースト妨害によるもの

(4) インパルス雑音など都市雑音によるもの

(1)は山かげでの受信では見受けられるが, 図 4 から わかるように，かなり $\mathrm{SN}$ 比が劣化した場合でも， $10^{-3}$ 程度のビット誤り率は確保できるので, 通常は それほどの問題とはならない。ただし, 極端に SN 比 が劣化した場合には, 再生クロック信号はノイズによ るジッタを含むことになるので，その分だけビット誤 り率は図 4 より悪くなるものと考えられる.

(2)は放送波多段中継での問題である．3 章での検討 は, 伝送特性のうち位相特性は直線とみなして, 振幅 特性にのみ着目したものであった。しかし現実には, 位相特性は必ずしも直線ではなく，信号エネルギーが 低域側に片寄っている NRZ 信号では, 特に低域での 群遅延特性が信号波形に悪影響を及ぼすことが広く知 られている.放送波中継では, 周波数変換, スプリア ス除去, 残留側波帯伝送, 妨害波除去等のため多数の フィルタが入り, 総合的な群遅延特性を劣化させてい る。な招, 放送波多段中継 1 段当りの平均群遅延時間 は $70 \mathrm{~ns}$ 程度といわれている ${ }^{6)}$.

一方, 受信機の標準的な特性を仮定した各種シミュ レーション結果からは, 低域群遅延時間が $150 \mathrm{~ns}$ 以 下でのアイ開口の差はそれほどでないが，これ以上の 遅れになると急激にアイ開口率が低下することが報告 されている4).したがって，放送波多段中継では， 2 または 3 段ごとの位相等化が必要になる.
(3)のゴースト妨害については, ゴーストが近接の場 合はDU 比があまり大きくとれないことが多く, 文 字信号の劣化に直接つながるので特に注意する必要が ある.ゴースト妨害の影響は, 遅延時間, 搬送波位相 差, DU 比等によって様々に異なる. ある程度の DU 比が保たれている範囲内では，搬送波位相差が $0^{\circ}$ の ときアイ開口率が最も劣化する. 直接波に対する反射 波の比を $R$ とすると, ゴースト妨害時のアイ開口率 $\eta$ は,

$$
\eta=\frac{1-R}{1+R}
$$

で表せる.

ゴースト妨害は, 通常のテレビ画面においても当然 障害となるが, 数 $\mu \mathrm{S}$ 以下の近接ゴーストでは, 位相 差によっては, かえって主観評価値が上るので, 文字 放送の場合は充分注意する必要がある。ただし，この 近接ゴーストについては, 受信側のアンテナの位置調 整, ゴースト対策アンテナの使用, あるいは, チュー ナ部のシールド対策等により解決できる場合が多い. また，適応制御型のゴーストキャンセラも開発されて いる.

(4)のインパルス雑音によるビット誤りの程度は, 妨 害波の DU 比によって異なるが, 受信機側の対策に よって解決するのは現状では困難である. 我が国の文 字放送で採用している $(272,190)$ 符号*による誤り訂 正方式は, 特にインパルス雑音の影響に強い方式とし て開発されたものである7).

上記以外にも受信機の問題として,アイ開口率を低 下させるVSB-AM 伝送特有の包絡線検波時のひず み, 同期検波時の再生搬送波位相差によって生じる直 交ひずみがあるが，詳細は省略する。

* 多数決論理回路で復号可能な $(273,191)$ 差集合巡回符号 ${ }^{8)}$ を 1 ビ ット分短縮したもの. 


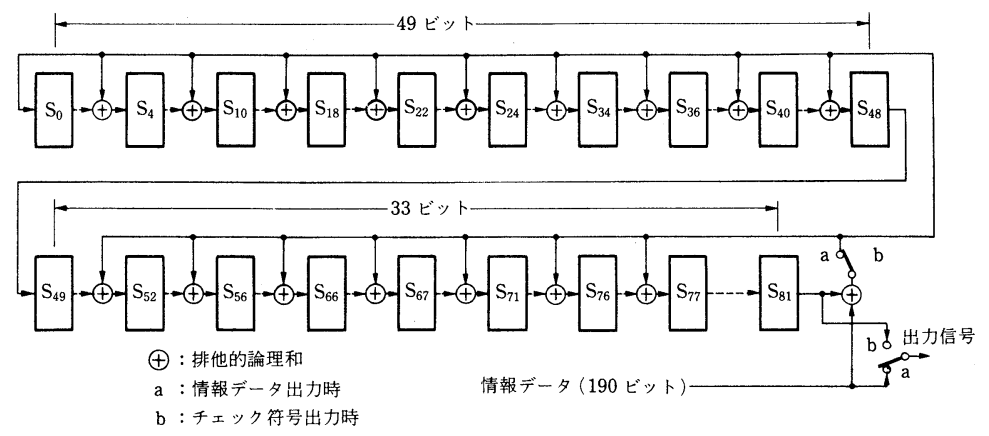

図 $5(272,190)$ 符号の符号化回路構成

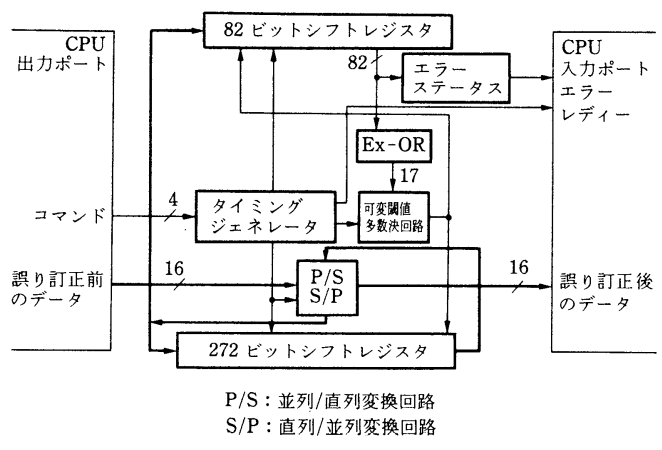

図 6 （272，190）符号復号回路の構成

\section{5. 文字放送サービスの伝送品質}

\section{1 誤り訂正方式}

放送波は，ディジタル信号の伝送路としては最悪な ものであり, しかも多数の受信者を対象とするため, 誤りの影響も非常に大きい。したがって, 受信機側で ビット誤りを自動的に訂正する誤り訂正符号の採用が 必須の条件になる。

我が国の文字放送では，外国のテレテキストには見 られない強力な誤り訂正能力をもつ $(272,190)$ 符号 を採用している。この符号は，実際に野外で収集した ビット誤りパターンを用いた種々のシミュレーション の結果から，最適なものとして採用が決まったもので ある。

生成多項式は

$$
\begin{aligned}
G(x)= & x^{82}+x^{77}+x^{76}+x^{71}+x^{67}+x^{66}+x^{56} \\
& +x^{52}+x^{48}+x^{40}+x^{36}+x^{34}+x^{24} \\
& +x^{22}+x^{18}+x^{10}+x^{4}+1
\end{aligned}
$$

で示される。

(272, 190) 符号の誤り訂正能力は, 272 ビット中 8 ビットであるが, 復号アルゴリズムの改良によって, 9 ビット以上の誤りに対する訂正確率を増大させ，実
質的には 11 ビット程度まで訂正能力を上げるように しており，市販されている LSIにもこのアルゴリズ ムが組み込まれている 符号化回路と復号回路を図 5 と図 6 に示す。

文字放送の伝送信号とページデータの伝送例を図 7 と図 8 に示す.CR はクロック同期をとるための 16 ビットの $1 ， 0 ， 1 ， 0 ， \cdots \cdots .$. 信号であり，FC は信号の 区切りを識別するための 8 ビットの一定パターン信号 である．FCの妨害に対する誤り率特性が $(272 ， 190)$

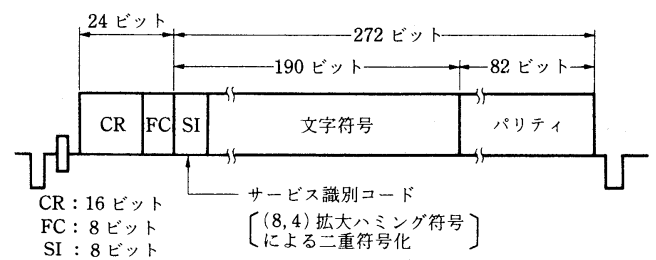

図 $7(272,190)$ 符号の伝送パケット形式

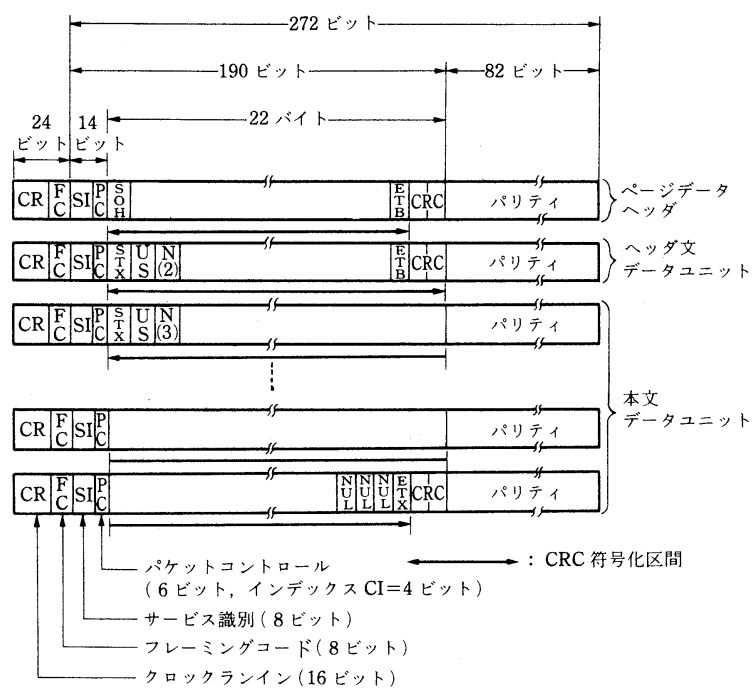

図 8 ページデータの伝送

テレビジョン学会誌 Vol. 42, No.6 (1988) 


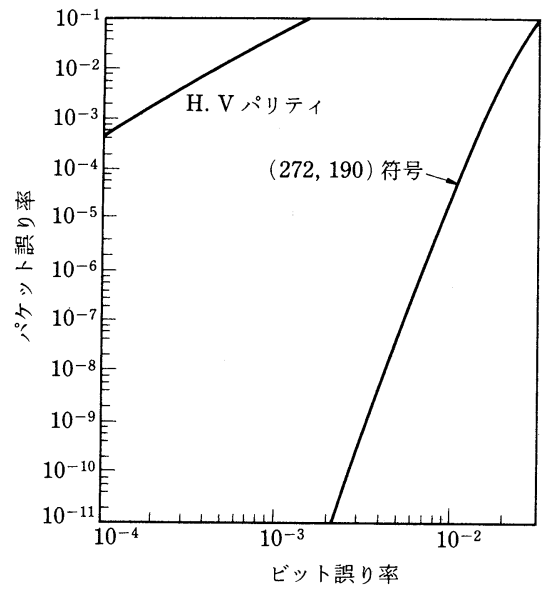

図 9 誤り訂正能力の比較

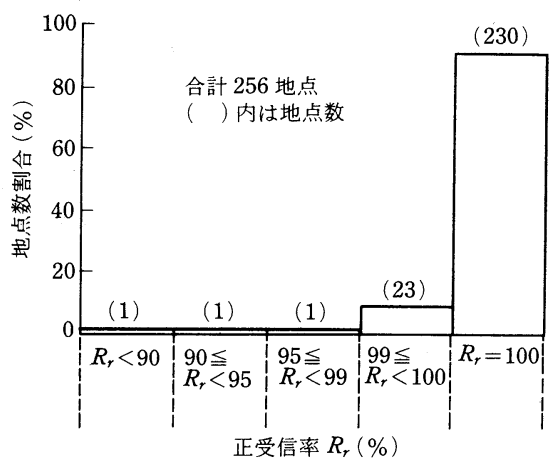

図 10 文字放送正受信率の分布

符号の誤り率特性に比べ劣っているため, 送り側で は, クロックと FC の位相を毎回同じ位相で送るよう にし，受信側では，FC 信号のタイミングの積分回路 を利用した前方保護によって FCの受信を強化する。 北米テレテキスト (NABTS) で用いられている 1 パケ ット中 1 ビットの誤り訂正能力をもつ水平・垂直パリ ティ符号と, $(272,190)$ 符号, 各々の誤り訂正能力を 図 9 に示す.

(272，190)符号で誤り訂正検出ができなかったパケ ット，あるいは，同期乱れなどによってパケット抜け を生じた場合は，16ビット CRC によって誤り検出が できる．(272，190）符号とCRCの組合せによって， 我が国の文字放送では，誤字・欠字がほとんど見られ ず，1 1ビットの愦りであっても重大な障害となるコン ピュータプログラムを伝送するテレソフトウェア放送 への適用も可能になっている.

\section{2 サービスエリア}

方式の最終決定に際して，実際に試験電波を発射し

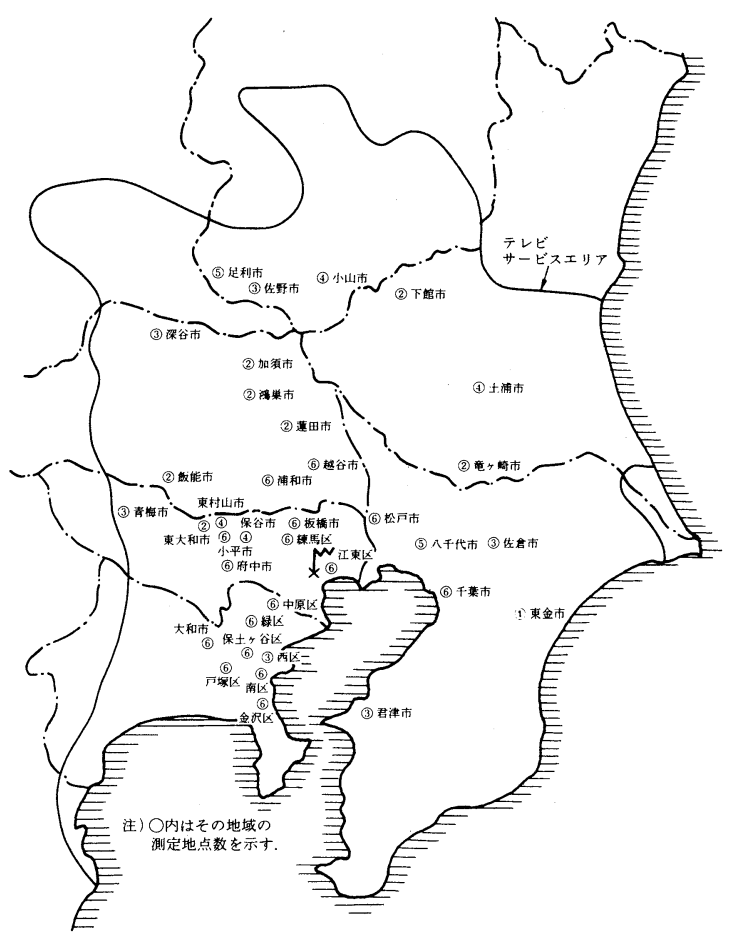

図 11 東京地区測定地点（36 ブロック 155 地点）

表 2 テレビ画質代表評価値に対する正受信率の地点数分布 (合計 256 地点)

\begin{tabular}{|c|c|c|c|c|c|c|}
\hline & & \multicolumn{5}{|c|}{ テレビ画質代表評価値 $Q_{\mathrm{v}}$} \\
\hline & & 2 & 3 & 4 & 5 & 計 \\
\hline \multirow{6}{*}{$\begin{array}{l}\text { 正 } \\
\text { 受 } \\
\text { 信 } \\
\text { 率 } \\
R_{\mathrm{r}}\end{array}$} & $R_{\mathrm{r}}=100 \%$ & & 55.4 & 33.2 & 1.2 & 89.8 \\
\hline & $99 \% \leqq R_{\mathrm{r}}<100 \%$ & 0.8 & 7.0 & 1.2 & & 9.0 \\
\hline & $95 \% \leqq R_{\mathrm{r}}<99 \%$ & & 0.4 & & & 0.4 \\
\hline & $90 \% \leqq R_{\mathrm{r}}<95 \%$ & & 0.4 & & & 0.4 \\
\hline & $R_{\mathrm{r}}<90 \%$ & 0.4 & & & & 0.4 \\
\hline & 計 & 1.2 & 63.2 & 34.4 & 1.2 & 100 \\
\hline
\end{tabular}

東京・大阪のサービスエリア内を無作為に抽出した 256 地点で受信実験を行い，次式に示すぺージ誤り率 の測定が NHK と民放各社によって行われた．図 10 にその結果を示す ${ }^{10)}$.

ページ誤り率

$=\frac{\text { 受信側でビット誤りを含んだページ数 }}{\text { 送出全ぺージ数 }}$

$=1$-正受信率

なお,ここでいう 1 ページとは, 12 パケットで構 成される最も一般的な文字画面である. 図 11 は東京 
地区における測定地域と地点数を, 表 2 にはテレビ画 質の総合評価値と正受信率地点数割合との関係を示 す。この測定では, $99 \%$ 以上の正受信率が得られる地 点数は $98.9 \%$ (95\%信頼区間 96.9 99.8\%) であるこ とがわかっている。この結果から, テレビサービスエ リアのほとんどの地点で文字放送の受信が可能であ り,サービスエリアもほほ同一であるとされている。

\section{6. むすび}

地上放送におけるディジタル伝送の基本的な問題点 と, 我が国の文字放送の伝送品質について解説的に述 べた

地上系の放送伝送路は, ゴースト等の妨害が多く, ディジタル伝送路としては最悪である.アイ開口率等 のディジタル伝送特性を余裕をもって設計したとして も, 少々のアイ開口率の差には関係なく, どのような 誤り訂正方式によってデー夕を保護するかによって, そのシステムの最終的な伝送品質が決定されてしま う.

欧米のテレテキストの方式は，どれも誤り訂正能力 が低いことから, テレソフトウェア放送, 業務用のテ レテキスト等では難点があり, 誤り訂正方式の再検討 を強いられている(1112).

我が国の文字放送で採用している（272，190）符号 は, 訂正能力が強力であり, 復号回路も簡単なことか ら, 文字多重放送以外の FM 多重放送 ${ }^{13)}$ と衛星デー 夕放送 ${ }^{14)}$ への採用が決まっており，地上ファクシミリ 放送, 光カード, SS (Spread Spectrum) 通信 ${ }^{15)}$ 等へ の適用も検討されている.

(272，190)符号は, 文字放送の開発における大きな 成果であり, 上記のような文字放送以外への波及効果 も見られるが, 将来のさらに高い周波数を用いる衛星 ディジタル放送, 劣悪な受信条件となる携帯あるいは 自動車向けのディジタル放送では, ビット誤り率が $10^{-2}$ を越える伝送にも充分使用できる, より強力な 誤り訂正符号の実用化が重要になってくると考えられ
$ろ^{16)}$.

(昭和 63 年 3 月 8 日受付)

\section{〔参考 文 献〕}

1）大井田ほか：“小特集, 文字放送” , テレビ誌, 40, 1, pp. 2-45 (1986)

2）沢辺ほか：“文字多重放送”，信学誌, 70, 1, pp. 37-58（1987）

3）上原ほか：“テレビ電波に多重するディジ夕ル信号の伝送パ ラメー夕の決定”, NHK 技術研究, 36, 1, pp. 28-59 (1984)

4）W. R. Bennett, 甘利訳：“デー夕伝送” , pp. 55-63, ラティス 社 (1966)

5） B. P. Lathi, 山中訳：“ディジタル・アナログ通信方式”, pp. 168-170, ホルトサウンダース社 (1985)

6）御園生, 上原, 長谷川：“放送波多段中継における VBL 重畳 パルス伝送特性”, テレビ学技報, 2, 21, IT 35-1, pp. 1-8 (1979)

7) 山田, 柳町, 磯部: “符号化伝送方式文字放送用誤り訂正方式 の開発”, NHK 技術研究, 37, 1, pp. 38-67 (1985)

8) E. J. Weldon, Jr.: "Difference-Set Cyclic Codes", BSTJ, 45, 7, pp. 1045-1055 (1966)

9）山田ほか：“(272, 190) 符号復号 IC とその誤り訂正能力”, 信学技報, IT 87-14, pp. 31-38（1987）

10）山田, 村崎, 田中：“文字放送サービスエリア確認の野外実験 結果”, NHK 技研月報, 28, 8, pp. 32-38（1985）

11）山田：“GLOBECOM' 84 への出席と欧米における文字・衛 星放送技術の調查”, NHK 技研月報, 28, 4, pp. 36-42（1985）

12) B. C. Mortimer, M. J. Moore and M. Sablatash: "The Design of a High-Performance Error-Correcting Coding Scheme for the Canadian Broadcast Telidom System Based on Reed-Solomon Codes", IEEE J., COM-35, 11, pp. 1113-1123 (1987)

13）黑田, 山本, 山田：“FM 多重ディジタル伝送方式” , テレビ 全大, 9-20 (1987)

14）斉藤, 木村, 河合：“衛星放送データチャンネルの誤り率特性 とパケット伝達方式の検討”, 信学技報, 84, 330, CS 84-190, pp. 95-101 (1985)

15）浜津ほか：“SAW コンボルバのスペクトラム拡散通信への 応用”, 信学会スペクトル拡散通信研究会, SS 87-19, pp. 1014 (1987)

16）黒田, 山田：“多数決論理素子で復号可能な符号に関する一 考察”, 信学技報, 87, 346, IT87-90 pp. 1-6 (1988)

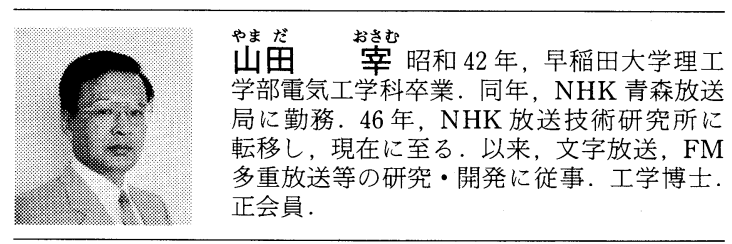

